\title{
RESEARCH OF SOME MAIZE HYBRIDS FROM CROATIA COMPARING KOSOVO'S AGRO-ECOLOGICAL CONDITIONS
}

\author{
${\text { Bakir Kelmendi }{ }^{1} \text {, Ismajl Cacaj }}^{2}$, Defrime Berisha ${ }^{3}$, Arsim Elshani ${ }^{4}$, Nazmi Hasanaj $^{5}$ \\ 1,2*4 University of "Haxhi Zeka", Faculty of Agribusiness, Peja 30000, Kosovo; \\ ${ }^{3}$ Kosovo Institute of Agriculture - KIA, Peja 30000, Kosovo; \\ ${ }^{5}$ Seeds factory "Koal seeds", Istog 30000, Kosovo; \\ *Corresponding author Ismajl Cacaj, e-mail: ismajl.cacaj@unhz.eu;
}

Received June 2019; Accepted August 2019; Published October 2019;

DOI: https://doi.org/10.31407/ijees9413

\begin{abstract}
Six maize hybrids $F_{1}$ generation from Croatia were tested, during the growing season, in agro - climatic condition of Kosovo. The investigation has been performed in micro trials set up at the two most important agro production sites of Kosovo, Peja and Pestova, in which trials has been investigated the yield, crude, protein, content and other relevant traits of. Maize (Zea mays L.) is one of the most important field crops that are regularly cultivated each year in Kosovo with an area 70000 - 90000 ha with some oscillation [3]. Grain yield per surface unit is one of the most important trains that influence directly for arent ability and economic production [9]. The average grain yield of maize in the last years the main agro- production localities of Kosovo is very low ranging from $4.0-5.5 \mathrm{t} / \mathrm{ha}$. For an economic and sustainable production of maize there is necessary to have high yield hybrids, optimal agro-climatic conditions, modern agriculture mechanization and application of proper plant protection measures the yield is very complex trait that depends by genotype of maize and environment conditions, as well [1], [2]. During the cropping season, the micro trials were established in two most important agro - production localities of Kosovo to investigate the performance of ten maize hybrids from the region with the aim of their introduction into the national list of varieties Kosovo. The perspective maize hybrids. The obtained result showed that there are statistically significant differences among the maize hybrids compared with standard check, with regard to the grain yield, crude, protein contents and other traits. Such statistically significant differences have been observed between localities as well.
\end{abstract}

Key words: crude protein content, grain Yield kg/plot, grain yield, phenological traits of maize hybrids. 